\title{
Compressive Creep Properties of Synthetic Fiber and Regenerated Fiber Assemblies under High Humidity Environment
}

\author{
NAKaJima Chie ${ }^{\text {a }}$, Yoneda Morihiro ${ }^{\text {b, * }}$ \\ ${ }^{a}$ Graduate School of Human Culture, Nara Women's University, Kitauoya-Nishimachi, Nara 630-8506 Japan \\ ${ }^{\mathrm{b}}$ Faculty of Human Life and Environment, Nara Women's University, Kitauoya-Nishimachi, Nara 630-8506 Japan
}

Received 28 June 2012; accepted for publication 10 October 2012

\begin{abstract}
In this study, a compression creep behavior of three-dimensional fiber assembly for futon wadding use is investigated under high humidity condition, which simulates sleeping microclimate condition. Compression creep tester is used for the measurement, and humid air is supplied to the tester with high humidity air generator. Samples used are twelve kinds of staple fiber made of polyester (PET) fiber with round, w-shaped and hollow section, polytrimethyleneterephtalate (PTT) fiber, cupra-ammonium (cupra) fiber and Lyocell fiber. Results are obtained as follows.

(1) Compression creep deformation ratio of regenerated fiber assembly is significantly large compared to that of synthetic fiber assembly for high and low stress.

(2) The order of creep deformation ratio for the same fineness and fiber diameter is as follows. Cupra is the largest, PET with round section follows and PET with $\mathrm{w}$-shaped section is the smallest for fineness of 1.4 dtex and fiber length of $38 \mathrm{~mm}$. PET with hollow section is larger than PET with round section for $6.6 \mathrm{dtex}$ and $51 \mathrm{~mm}$

(3) There is no significant difference in compression creep deformation ratio for staple fiber assembly made of same fiber material of which fineness ranges $1.3 \sim 6$. dtex and fiber length ranges $38 \sim 51 \mathrm{~mm}$.

(4) Compression creep deformation ratio in high stress condition (2156 Pa) is larger than that of low stress condition $(1176 \mathrm{~Pa})$.

(5) Compression creep behavior of staple fiber in high humidity condition is expressed as following equation. $\varepsilon_{\mathrm{t}}=\mathrm{Y}_{0} \ln (\mathrm{vt}+1)$
\end{abstract}

where, $\mathrm{Y}_{0}$ and $\mathrm{v}$ are constants derived from measurement curve.

(6) $Y_{0}$ is the magnitude of compression creep at a certain time, and $V_{\text {ini }}\left(=Y_{0} \cdot v\right)$ is the initial tangential rate of creep. Parameters $Y_{0}$ and $V_{\text {ini }}$ is useful for describing compression creep behavior of synthetic and regenerated fiber assembly.

Key Words: Compression creep, Synthetic fiber, Regenerated fiber, Fiber assembly, High humidity

\section{高湿環境下における合成䋊維・再生繊維集合体の圧縮クリープ特性}

\author{
中島千恵 ${ }^{a}$, 米田守宏 ${ }^{b, *}$ \\ ${ }^{a}$ 奈良女子大学大学院人間文化研究科, ${ }^{b}$ 奈良女子大学生活環境学部
}

\section{1. 緒 言}

寝具は快適な睡眠を実現し, 心身の健康を維持する機能を 備えている必要がある. 睡眠中のからだの生理的変化（寝返
り・発汗・体温低下など）を妨げない寝具が, 良い寝具とさ れており, 敷きふとんには保温性・吸放湿性・透湿性・快適 支持性（硬さ）・クッション性が求められている。筆者らは, 敷きふとんの中わた部材を構成している合成繊維や再生繊維 からなる短繊維集合体についての圧縮粘弾性特性を明らかに

\footnotetext{
* 連絡先：奈良女子大学生活環境学部 630-8506 奈良市北魚屋西町 E-mail: yoneda@cc.nara-wu.ac.jp, Tel/ Fax : +81-742-20-3463
} 
し，商品開発をする上で必要な製品設計指針および寝心地に 関わる実使用性能に関する知見を得るため, 現在流通してい る異型断面や中空断面ポリエステル繊維, ポリトリメチレン テレフタレートおよびキュプラやリヨセルなどの再生セル ロース系繊維などの多種多様なわたを採り上げ, 等速繰り返 し圧縮・回復特性, 圧縮応力緩和特性, 圧縮クリープ特性に ついて研究を行なってきた $[1-5]$.

寝具を構成している繊維素材は, 睡眠中にからだから発生 する不感蒸泄や汗などの水分を吸収すると，寝具の中でもと くに敷きふとんを構成している中わた部材の力学特性は, 大 きく変化するものと考えられる。これまで，緘維集合体の圧 縮に関連する研究は数多いが [6-10], 高湿条件下での研究 は数少ない [11]. また, キュプラや異形断面ポリエステル など, 最近の寝装用途に流通している短繊維集合体を採り上 げ，短繊維の集合構造体としての粘弾性変形に粘弾性理論を 応用した圧縮研究はほとんど見うけられない. そこで前報 ［5］では高湿環境を継続的に維持できる加湿槽を試作し，長 時間にわたって高湿環境下において圧縮応力緩和試験を行う ことのできるシステムを作製した。このシステムを用いて， これら試料について吸湿による圧縮特性の変化を粘弾性特性 の変化として捉えることを試みた。 その結果, 吸湿性の高い キュプラ短繊維からなる繊維集合体については, 繊維内部に 存在する水分の影響が顕著に現れており, 標準試料と高湿試 料のそれぞれの粘弾性的性質の相違を明確にしてモデル表示 し, 短繊維自体及び繊維集合体に及ぼす水分の効果を捉える ことができた。さらに疎水性のポリエステル繊維集合体は キュプラ繊維集合体とは水分効果のメカニズムが異なること を明らかにした。

圧縮粘弾性特性に関しては, 応力緩和試験と並んでもう一 つ重要で基本的な試験法としてクリープ試験があるが, 標準 条件での圧縮クリープ特性について検討した前報 [4]にお いて, 非線形 3 要素モデルから導かれるクリープ表示式を報 告している。圧縮クリープ試験は敷きふとんなどの寝装用途 の製品設計を行う場合，および実使用時の寝心地に関わる快 適性や長時間使用時におけるへたり現象など寸法安定性の良 し悪しを評価するという観点からも必要な試験法であるた め, 実使用に近い高湿環境での検討が重要であると考えられ る.

本研究では, 高湿環境下における圧縮クリープ特性につい て検討を加えることとした。実験試料として，これまでの研 究 [1-5］で使用した, 異型断面ポリエステル，丸断面およ び中空断面ポリエステル，ポリトリメチレンテレフタレート などの合成繊維や，キュプラおよびリヨセルなどの再生繊維 について 12 種の短繊維集合体を用いて, これら試料の高湿 環境下における圧縮クリープ特性とその機構について粘弾性 モデルにもとづいて検討した結果を報告する.

\section{2. 実 験}

\section{1 試料}

実験に使用した短繊維材料は異型断面ポリエステル 3 種, 丸断面ポリエステル 3 種, 中空断面ポリエステル 1 種, ポリ トリメチレンテレフタレート 1 種, キュプラ 3 種, リヨセル 1 種の計 12 種である。 これらの原綿を開繊し, カーディン グしたウェブを用い, 標準状態 $\left(20 \pm 2{ }^{\circ} \mathrm{C}, 65 \pm 2 \% \mathrm{RH}\right)$ の環境条件中で 24 時間以上調湿した後に実験に供した。こ れら試料の記号を Table 1 に，その性状を Table 2 に示す。 圧縮クリープ試験における主要な測定条件として繊維体積率 および最大圧縮応力があるが，これは前報［4］で報告した 標準試料での圧縮クリープ試験と同様の測定条件で行った. 市販敷きふとんの標準寸法（縦 $200 \mathrm{~cm} \times$ 横 $100 \mathrm{~cm} \times$ 厚み 8 $\mathrm{cm})$ および中わた重量 $(4 \mathrm{~kg})$ から標準体積率を 0.025 $\mathrm{g} / \mathrm{cm}^{3}$ とし, 必要な試料重量は合成繊維の場合, 約 $6.9 \mathrm{~g}$, 再 生繊維の場合，約 $7.5 \mathrm{~g}$ を設定した。

測定に供する試料の調整を以下のように行った。 $10 \mathrm{~cm} \times$ $10 \mathrm{~cm}$ の大きさに切った一定量のウェブ状短繊維材料を, 底 面が一辺 $10 \mathrm{~cm}$ の正四角柱セル内に積層状に充填する。その 後四角柱から抜き取り，50 g のプラスチック板を載せ，相対 湿度が約 100\% RH の高湿度条件を保つプラスチックケース 内で 2 時間放置したものを実験試料とする。

クリープ試験を行うさいの圧縮応力は前報 [4] での実験 条件をもとに, $1176 \mathrm{~Pa}$ および $2156 \mathrm{~Pa}$ の 2 通りとする。 こ れは，体重 $65 \mathrm{~kg}$ の人体が就寝時に敷きふとんに及ぼす平均 圧力が約 $2300 \mathrm{~Pa}$ であるという報告 [12］に基づいて，圧縮 応力 $2156 \mathrm{~Pa}$ 及び $2156 \mathrm{~Pa}$ の約半分の $1176 \mathrm{~Pa}$ を設定した。 以下, $1176 \mathrm{~Pa}$ を低圧縮応力条件, $2156 \mathrm{~Pa}$ を高圧縮応力条件 と呼ぶことにする.

Table 1 Sample code.

\begin{tabular}{|c|c|}
\hline Sample code & Detail of sample \\
\hline WPE-1 & \multirow{3}{*}{$\begin{array}{l}\text { Polyester staple fiber with } \mathrm{w}^{-} \text {-shaped heteromorphic } \\
\text { section }\end{array}$} \\
\hline WPE-2 & \\
\hline WPE-3 & \\
\hline RPE-1 & \multirow{3}{*}{ Polyester staple fiber with round section } \\
\hline RPE-2 & \\
\hline RPE-3 & \\
\hline RPE-4 & Polyester staple fiber with hollow section \\
\hline PTT & Polytrimethyleneterephtalate staple fiber \\
\hline $\mathrm{CU}-1$ & \multirow{3}{*}{ Cupra-ammonium (Cupra) staple fiber } \\
\hline $\mathrm{CU}-2$ & \\
\hline $\mathrm{CU}-3$ & \\
\hline LY & Lyocell staple fiber \\
\hline
\end{tabular}


Table 2 Details of fiber samples for wadding use.

\begin{tabular}{|c|c|c|c|c|c|c|c|c|}
\hline Sample code & $\begin{array}{l}\text { Fineness } \\
(\text { dtex })\end{array}$ & $\begin{array}{l}\text { Fiber length } \\
\quad(\mathrm{mm})\end{array}$ & $\begin{array}{l}\text { Fiber diameter } \\
\qquad(\mu \mathrm{m})\end{array}$ & $\begin{array}{c}\text { Specific } \\
\text { gravity } \\
\text { (n.d.) }\end{array}$ & $\begin{array}{c}\text { Number } \\
\text { of crimp } \\
\text { (unit/25mm) }\end{array}$ & $\begin{array}{c}\text { Percentage } \\
\text { of crimp } \\
(\%)\end{array}$ & $\begin{array}{c}\text { Apparent young's } \\
\text { modulus } \\
\left(\mathrm{kg} / \mathrm{mm}^{2}\right)\end{array}$ & $\begin{array}{c}\text { Bending rigidity } \\
\quad\left(\mathrm{gf} \cdot \mathrm{cm}^{2}\right)\end{array}$ \\
\hline \multirow{2}{*}{ WPE-1 } & \multirow{2}{*}{1.4} & \multirow{2}{*}{38} & $24.22^{* 2}$ & \multirow{2}{*}{1.38} & \multirow{2}{*}{23.13} & \multirow{2}{*}{14.80} & \multirow{2}{*}{318} & $5.37 \times 10^{-5 * 4}$ \\
\hline & & & $6.27^{* 3}$ & & & & & $2.41 \times 10^{-7 * 5}$ \\
\hline \multirow{2}{*}{ WPE-2 } & \multirow{2}{*}{1.4} & \multirow{2}{*}{51} & $24.31^{* 2}$ & \multirow{2}{*}{1.38} & \multirow{2}{*}{19.25} & \multirow{2}{*}{34.71} & \multirow{2}{*}{291} & $4.99 \times 10^{-5 * 4}$ \\
\hline & & & $6.78^{* 3}$ & & & & & $3.01 \times 10^{-7 * 5}$ \\
\hline \multirow{2}{*}{ WPE-3 } & \multirow{2}{*}{2.2} & \multirow{2}{*}{$\mathrm{B} 64^{* 1}$} & $29.06^{* 2}$ & \multirow{2}{*}{1.38} & \multirow{2}{*}{22.63} & \multirow{2}{*}{28.29} & \multirow{2}{*}{297} & $1.04 \times 10-4^{* 4}$ \\
\hline & & & $8.71^{* 3}$ & & & & & $8.39 \times 10^{-7 * 5}$ \\
\hline RPE-1 & 1.3 & 38 & 12.76 & 1.38 & 17.00 & 26.70 & 412 & $5.36 \times 10^{-6}$ \\
\hline RPE-2 & 2.2 & 51 & 18.15 & 1.38 & 15.75 & 27.24 & 379 & $2.02 \times 10^{-5}$ \\
\hline RPE-3 & 6.6 & 51 & 29.17 & 1.38 & 10.25 & 33.33 & 262 & $9.31 \times 10^{-5}$ \\
\hline RPE-4 & 6.6 & 51 & 29.79 & 1.38 & 8.88 & 27.59 & 252 & $9.74 \times 10^{-5}$ \\
\hline PTT & 1.7 & 51 & 15.02 & 1.34 & 24.88 & 15.43 & 154 & $3.85 \times 10^{-6}$ \\
\hline $\mathrm{CU}-1$ & 1.4 & 38 & 11.84 & 1.50 & 10.63 & 8.79 & 645 & $6.22 \times 10^{-6}$ \\
\hline $\mathrm{U}-2$ & 1.4 & 51 & 13.73 & 1.50 & 15.06 & 12.75 & 639 & $1.11 \times 10^{-5}$ \\
\hline $\mathrm{CU}-3$ & 2.2 & 76 & 15.46 & 1.50 & 13.38 & 20.51 & 475 & $1.33 \times 10^{-5}$ \\
\hline LY & 7.0 & 64 & 33.56 & 1.50 & 5.88 & 14.62 & 359 & $2.23 \times 10^{-4}$ \\
\hline
\end{tabular}

*1 : bias cut

*2: a major-axis

*3: a minor-axis

$* 4:$ bending rigidity along the longer-axis direction

*5 : bending rigidity along the minor-axis direction

\section{2 実験装置および実験方法}

本研究では, 試作した圧縮クリープ測定装置（株カトー テック製）を，前報［5］で作製した加湿調整装置とともに 使用した。実験装置の概略を Fig. 1 に示す.

加湿調整装置は湿度発生装置と湿度調整槽および加湿槽か ら構成されている。これらは圧縮応力緩和試験を行うさいに 作製した装置を使用しており, 設定条件についても同様の条 件にて実験を行った。湿度発生装置の霧化量は $300 \mathrm{ml} / \mathrm{HR}$, エアー循環ファンの回転速度を $1000 \mathrm{rpm}$ とし, 流量 180 $\mathrm{L} / \mathrm{min}$ にて空気を循環させる，加湿槽（W250 × H170 × $\mathrm{D} 160 \mathrm{~mm}$ ) については圧縮クリープ測定装置全体をカバー し, 試料の出し入れや圧縮板の支柱調整をし易くするため, 外形を大きくするなどの改良を加えた。

本研究では, 吸湿性の高い再生繊維と吸湿性の極めて低い 合成䋊維の，吸湿による圧縮特性の違いを明確にする目的 で，測定条件として最も高い湿度条件を設定して圧縮クリー プ試験を行った。所定重量の試料を相対湿度が約 $100 \%$ RH のプラスチック容器の中で 2 時間放置し吸湿させると, キュ プラ繊維の水分率は $19.6 \%$, 試料内部の温湿度は $20.4^{\circ} \mathrm{C}$, $91.0 \%$ RH になる。 ポリエステル繊維については，水分率は $0.6 \%$, 試料内部の温湿度は $20.5^{\circ} \mathrm{C}, 94.7 \% \mathrm{RH}$ になる。また, 一般に夏季の寝床内湿度は $90 \%$ RH を超えると言われてい

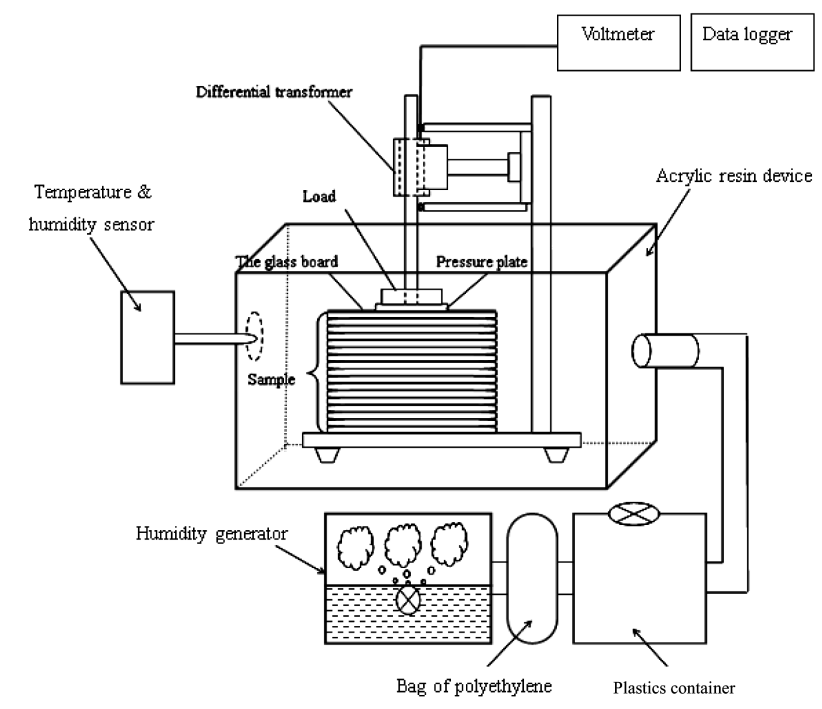

Fig. 1 The compressive creep experiment device.

ることも考慮に入れて, 試料を加湿するのに要する調整時間 は2 時間が適正であると判断した。 なお，PTT およびLYの 高湿度環境下での水分率については実測していないが, 次の ように考えられる.PTTはポリエステル系繊維の一つであ り, ポリエチレンテレフタレート（PET）と化学組成および 分子構造はほとんど同じであることから判断すれば, PTT 
の水分率はポリエステルとほぼ等しいと推測される。LYに ついては再生セルロース繊維の一つであり, CU と化学組成 および分子構造はほとんど同じであることから判断して, LY の水分率はCU とほぼ等しいと推測される.

繊維集合体の圧縮クリープ測定は次の手順にしたがって 行った。初めに, 所定の試験荷重を積載した圧縮板をゆっく りした速度で降下させ, 試料を試験荷重で圧縮する. 圧縮板 が接触した瞬間を時刻 $0 \mathrm{sec}$ とする。この瞬間に繊維集合体 はクリープ状態に入り, これ以後の変形をクリープ変形と規 定する. 圧縮板の支柱の移動量 (変位) を差動トランスで検

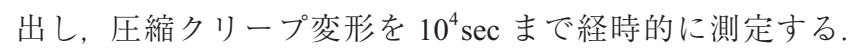
信号処理法として, 圧縮クリープ変形量に対応するアンプか らの出力電圧をデータロガーに取り込み, その後パソコンに てデータ処理を行った。

圧縮クリープ測定では前処理を施した積層状の試料に $1176 \mathrm{~Pa}$ および $2156 \mathrm{~Pa}$ の応力を負荷した。

圧縮クリープ変化率 Rt（\%）を以下のように定義する.

$$
R_{t}=\frac{\varepsilon_{t}}{\mathrm{~h}_{0}} \times 100
$$

$\mathrm{h}_{0}$ : 時間 $t=0$ における試料高さ $(\mathrm{mm})$

$\varepsilon_{t}$ : 任意時間 $t$ における圧縮クリープ変位量 $(\mathrm{mm})$

\section{3. 結果および考察}

\section{1 実験結果}

上述の実験方法にしたがって，12 試料の高湿環境下にお ける圧縮クリープ変形量を低圧縮応力および高圧縮応力のも とで測定した，得られた結果の一例を Fig. 2〜4に示す. Fig. 2〜4 は縦軸に圧縮クリープ変形量 $\varepsilon_{t}(\mathrm{~mm})$, 横軸は時間 $t(\mathrm{~s})$ を対数目盛で示している. Fig. 2 は WPE-1, 2, 3 と PTT, Fig. 3 は RPE-1, 2, 3 と RPE-4, Fig. 4 は CU-1, 2, 3 と LY につい て，いずれも低圧縮応力の場合を示している. Fig. $2 \sim 4$ よ り明らかなように, 圧縮クリープ変形曲線は $10 \sim 10^{4}$ 秒の時 間領域でほぼ時間の対数に対して下に凸な関数形状で増大し

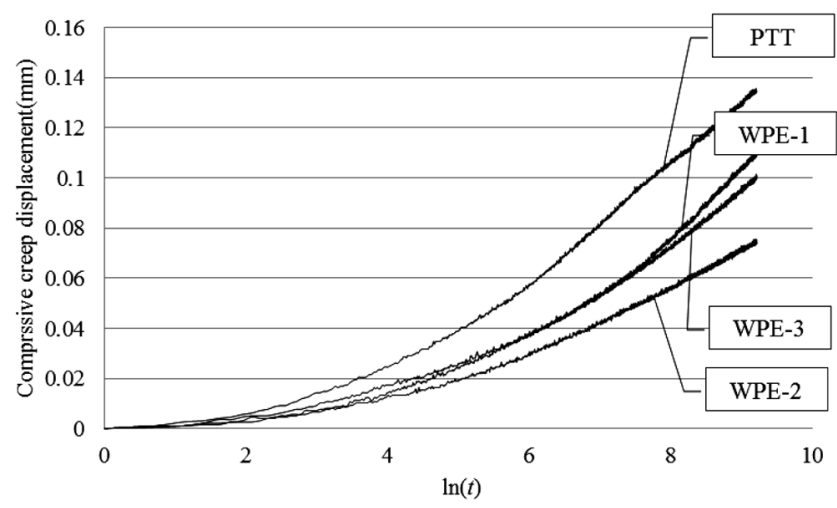

Fig. 2 The compressive creep displacement curve under the condition that compression stress is $1176 \mathrm{~Pa}$ and environment is high humidity.

Sample is WPE-1,2,3,4.

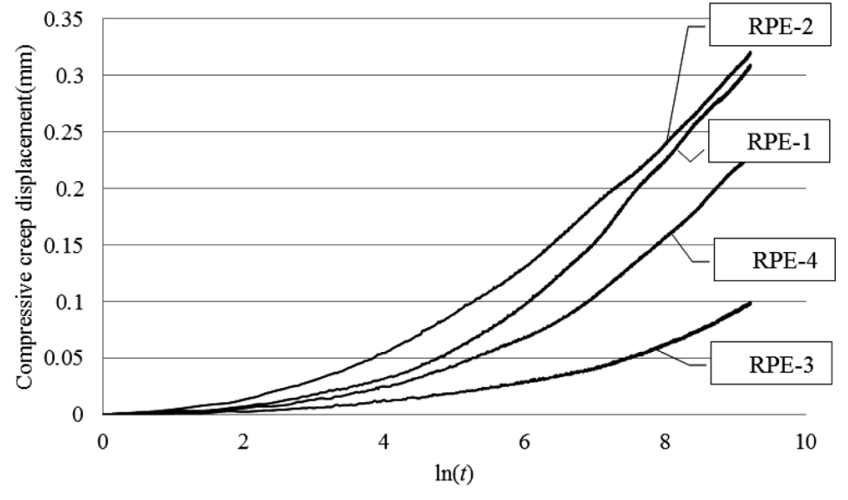

Fig. 3 The compressive creep displacement curve under the condition that compression stress is $1176 \mathrm{~Pa}$ and environment is high humidity.

Sample is RPE-1,2,3,4.

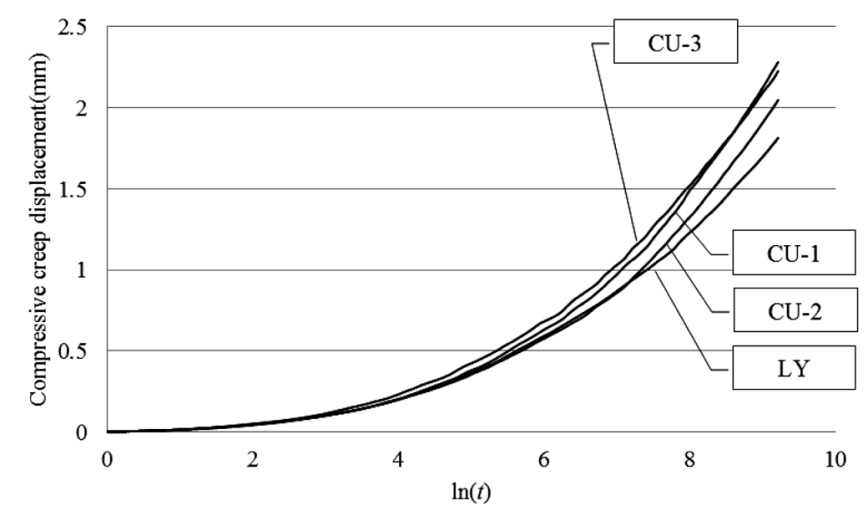

Fig. 4 The compressive creep displacement curve under the condition that compression stress is $1176 \mathrm{~Pa}$ and environment is high humidity.

Sample is CU-1,2,3 and LY.

ている.とくに, 再生繊維からなる短繊維集合体 $(\mathrm{CU}-1,2$, $3, \mathrm{LY})$ の圧縮クリープ変形量は, 合成繊維からなる短繊維 集合体よりも顕著に大きい.

繊度と繊維長がほぼ等しく，素材および繊維断面形状の異 なる WPE-1, RPE-1, CU-1 について標準試料と高湿試料の 圧縮クリープ挙動（1176 Pa）を比較した結果の一例を Fig. 5 に示す. WPE-1, RPE-1の圧縮クリープ変形は標準試料と 高湿試料では, 変位量において顕著な差はみられなかった が, CU-1 については Fig. 5 より, 標準試料に比べて高湿試 料の圧縮クリープ変形が極めて大きいことが明らかである.

次に, 実験から得られた圧縮クリープ変形率の結果について 述べる。

1 つめに試料種の違いによる圧縮クリープ変化率を調べ た. Fig. 6 に $10^{4}$ 秒後における低圧縮応力と高圧縮応力の圧 縮クリープ変形率を示す。各圧縮応力時での $10^{4}$ 秒における 圧縮クリープ変化率を比べると, 合成繊維に比べて再生繊維 からなる短繊維集合体の圧縮クリープ変形は大きい. 低圧縮 応力時では WPE-1,2,3 が $0.6 \sim 0.8 \%, \mathrm{RPE}-1,2,3$ が 


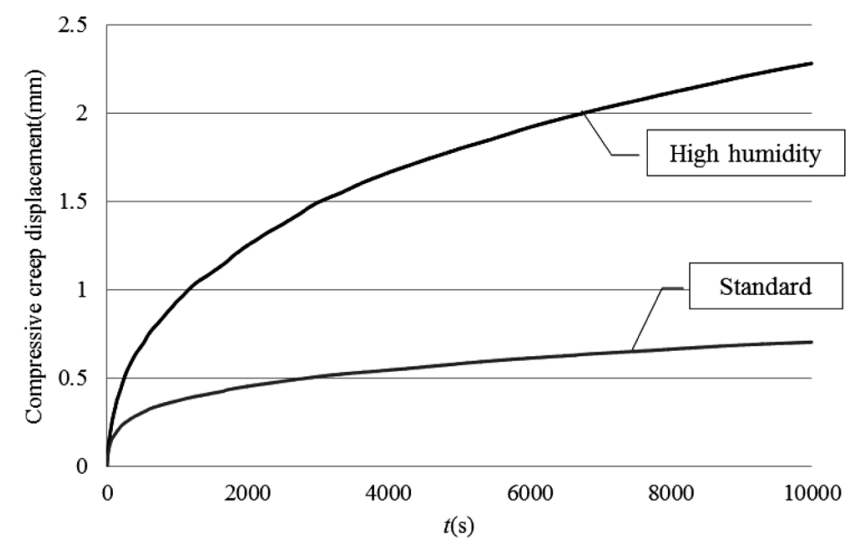

Fig. 5 The comparison between standard condition and high humidity condition for $\mathrm{CU}-1$.

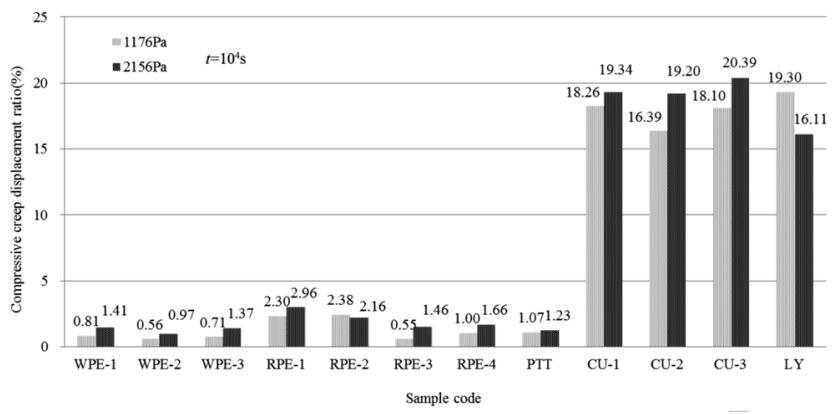

Fig. 6 The Compressive creep displacement ratio at $\mathrm{t}=10^{4} \mathrm{~s}$.

0.6 2.4\%, RPE-4 が $1.0 \%$, PTT が $1.1 \%$, CU-1,2,3 が 16.4 18.3\%, LY が 19.3\%である. 高圧縮応力時では WPE-1, 2, 3 が 1.0 1.4\%, RPE-1, 2, 3 が 1.5 3.0\%, RPE-4 が $1.7 \%$, PTT が $1.2 \%$, CU-1,2,3 が 19.2〜20.4\%, LY が $16.1 \%$ である。

ほぼ同一繊度（1.3 dtex または $1.4 \mathrm{dtex})$ および同一繊維長 (38 mm) の WPE-1, RPE-1 および CU-1 の圧縮クリープ変 形率を比較すると, 異型断面の WPE-1 が最も小さく, RPE-1，CU-1 の順で大きくなる. 同一繊度（6.6 dtex）およ び同一繊維長 $(51 \mathrm{~mm})$ の RPE-3 と RPE-4 を比較すると, RPE-3 に比べて中空断面の RPE-4 の方が圧縮クリープ変形 率は大きい. 以上は標準試料と同様の結果である。

2 つめに同一試料種における繊度と繊維長の違いによる圧 縮クリープ変形率を比較した。繊度と繊維長の違いによる顕 著な有意差は見られない，前報 [4] で報告したように，標 準試料の場合, WPE-1, 2, 3, RPE-1, 2, 3 はいずれも, 繊度 が小さく, 繊維長が短い程, 圧縮クリープ変化率は大きくな る傾向がみられた。一方, $\mathrm{CU}-1,2,3$ については低圧縮応力 時と高圧縮応力時では振る舞いが異なり, 低圧縮応力時は繊 度が大きく, 䋊維長が長い程クリープ変化率は大きい傾向が 見られたが, 高圧縮応力時は繊度が小さく, 繊維長が短い程, 圧縮クリープ変化率は大きくなるという結果を得た。そこで 高湿条件下および標準条件下で行なった結果を比較した。 WPE-1, 2, 3, RPE-1, 2,3, CU-1, 2, 3 について繊度と繊維長 の違いによる影響をみるため, $10^{4}$ 秒後のクリープ変形率を
両環境下で比較した結果を Fig. 7〜9に示す。標準試料，高 湿試料いずれの場合においてもほぼ同じ傾向を示しており, 本実験で用いた範囲の繊度（1.3～6.6 dtex）と繊維長（38～51 $\mathrm{mm} ）$ の違いはクリープ変形の大きさを左右するものではな いことがわかった。

3つめに圧縮クリープ変形の圧縮応力依存性について検討 する．各高湿試料についてそれぞれ低圧縮応力時と高圧縮応 力時における圧縮クリープ変形率を比較した. Fig. 6 より圧 縮クリープ変形率と圧縮応力との関係についてみると, RPE-2 と LY 以外の試料はすべて高圧縮応力時の方が低圧縮 応力時よりクリープ変形が大きい. すなわち圧縮応力依存性 があるといえる，RPE-2 は低圧縮応力時と高圧縮応力時で 顕著な差はない，LYについては低圧縮応力時に比べて高圧 縮応力時の方が圧縮クリープ変形は小さい結果となった. LY のみが他の試料と異なる振る舞いをした結果に対して, 今回の実験で用いた 1 点のみで考察することは難しいが, LY は他の試料に比べてかなり太繊度で且つ繊維長が長いこ とが関係していると考えられる。また, 非線形粘弾性挙動の 違いや, 試料調製段階 $(t<0)$ での変形の履歴も影響して いると推測される。

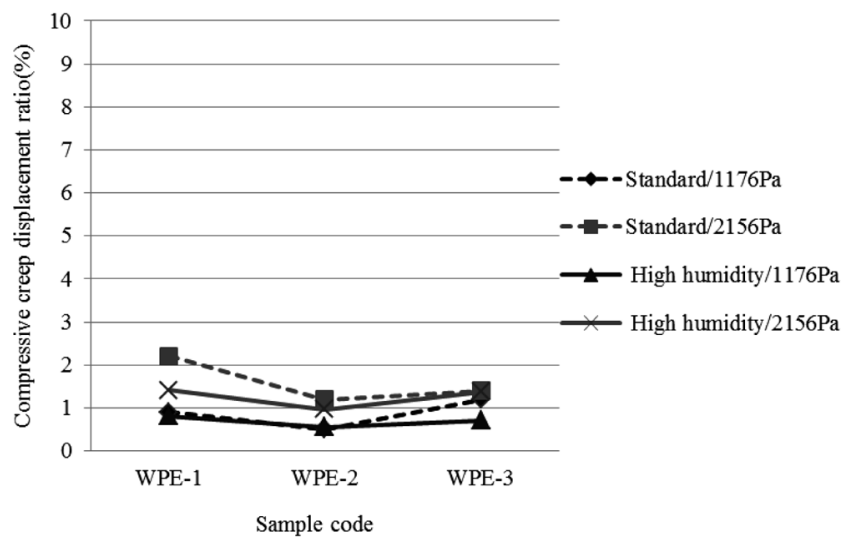

Fig. 7 The comparison of compressive creep displacement ratio between fineness and fiber length for WPE-1,2,3 at $\mathrm{t}=10^{4} \mathrm{~s}$.

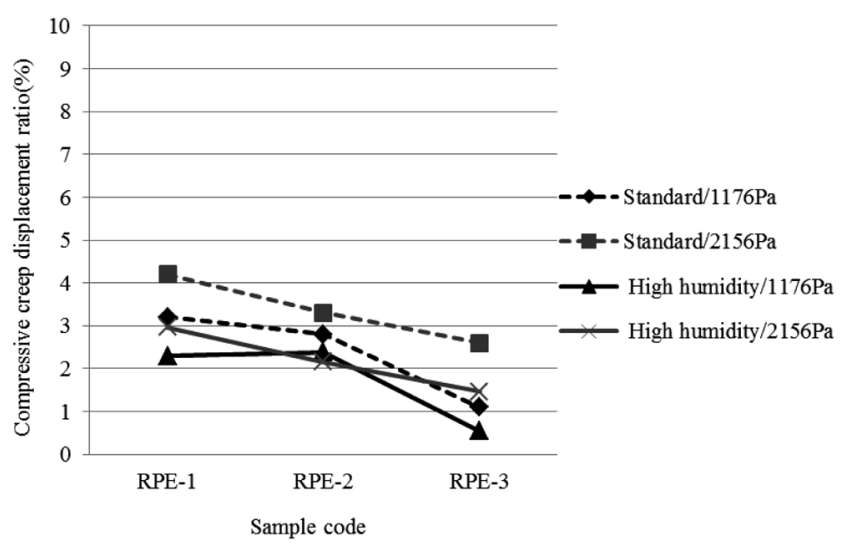

Fig. 8 The comparison of compressive creep displacement ratio between fineness and fiber length for RPE-1,2,3 at $\mathrm{t}=10^{4} \mathrm{~s}$. 


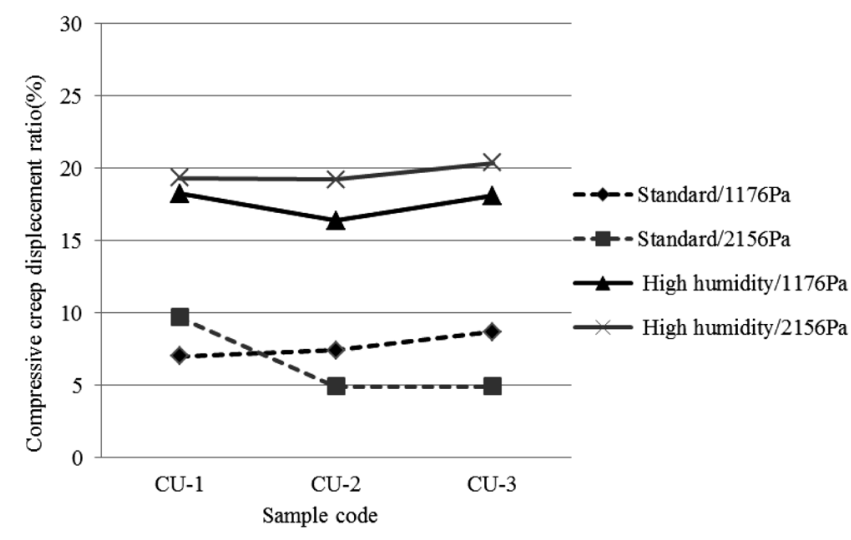

Fig. 9 The comparison of compressive creep displacement ratio between fineness and fiber length for $\mathrm{CU}-1,2,3$ at $\mathrm{t}=10^{4} \mathrm{~s}$.

\section{2 圧縮クリープ表示式の検討}

圧縮クリープ変位の時間変化に関する数式表示（クリープ コンプライアンス）について検討する，前報 [4] では，標 準状態 $\left(20^{\circ} \mathrm{C} ， 65 \% \mathrm{RH}\right)$ における合成繊維および再生繊維 からなる短繊維集合体の圧縮クリープ現象が, 次のクリープ 表示式によって表わすことができることを示した。

$$
\varepsilon_{t}=\mathrm{Y}_{0} \ln (v t+1)
$$

ここで $\mathrm{Y}_{0}(\mathrm{~mm})$ および $\mathrm{v}\left(\mathrm{s}^{-1}\right)$ は試料の物性や測定条件, 圧 縮応力などによって決まる定数である. 式(2)は, 綿繊維塊 の圧縮クリープ表示式として Fig. 10 に示す Eyring 粘性要素 を含む非線形 3 要素モデルから導かれている [10]。本報告 では, 高湿環境下においても, 圧縮クリープ挙動が標準試料

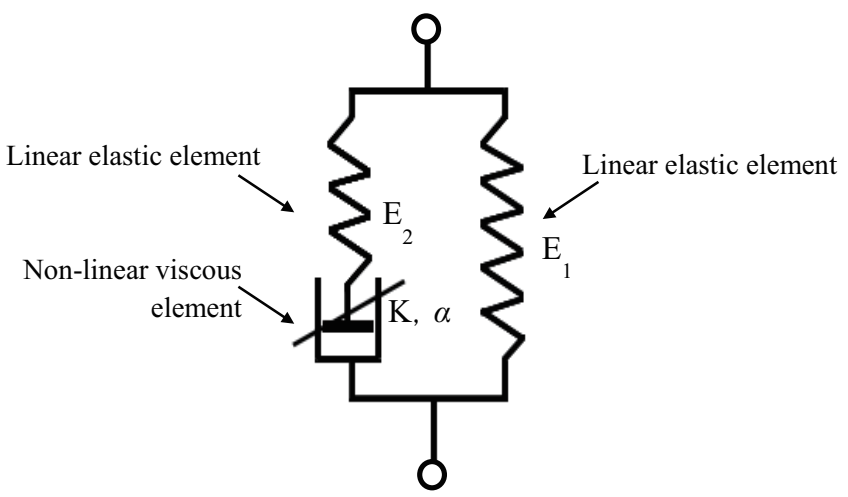

Fig. 10 Three element visco-elastic model including non-linear viscous element (dash pot).

と同様に非線形 3 要素モデルで表されるか否かについて検討 するため，(2)式を適用することにより短繊維集合体の圧縮 クリープ曲線を解析する。

3.1 の測定結果から式(2)の係数 $\mathrm{Y}_{0}$ および $\mathrm{v}$ を求め, 式(2) に代入して計算した曲線の数例を測定曲線とともに Fig. 11〜13 に示す。縦軸に圧縮クリープ変形量 $\varepsilon_{t}(\mathrm{~mm})$, 横軸は 時間 $t(\mathrm{~s})$ を普通目盛で示している。ここで図中の破線は式 (2)による計算曲線, 実線は測定曲線である。測定曲線と計 算曲線の一致はおおむね良好であると考えられる。したがっ て，非線形 3 要素モデルで説明できると推測される。たた し， $\mathrm{Y}_{0}$ および $\mathrm{v} の$ 值は, $t=10^{3}(\mathrm{~s})$ および $t=10^{4}(\mathrm{~s})$ におけ る $\varepsilon_{t}$ の実測值を式 (2)に代入し, 得られた 2 つの方程式を連 立させて解くことによって求めている。それぞれの試料にお ける $\mathrm{Y}_{0}$ および $\mathrm{v}$ の值を Table 3 に示す.

Table 3 The calculated values of coefficients, $\mathrm{Y}_{0}$ and $\mathrm{v}$ obtained from experimental curves.

\begin{tabular}{|c|c|c|c|c|c|c|c|c|c|c|c|c|c|c|}
\hline \multicolumn{3}{|c|}{ Sample code } & WPE-1 & WPE-1 & WPE-3 & RPE-1 & RPE-2 & RPE-3 & RPE-4 & PTT & $\mathrm{CU}-1$ & CU-2 & $\mathrm{CU}-3$ & LY \\
\hline \multirow{6}{*}{$\begin{array}{c}\mathrm{Y}_{0} \\
(\mathrm{~mm})\end{array}$} & \multirow{3}{*}{$1176 \mathrm{~Pa}$} & Standard & 0.014 & 0.014 & 0.0177 & 0.0501 & 0.0337 & 0.0202 & 0.0235 & 0.0098 & 0.1445 & 0.1313 & 0.1521 & 0.1424 \\
\hline & & High humidity & 0.0251 & 0.0251 & 0.0217 & 0.0703 & 0.0608 & 0.0253 & 0.0559 & 0.0239 & 0.5851 & 0.5290 & 0.5352 & 0.4237 \\
\hline & & $\begin{array}{c}\text { Ratio of High humidity } \\
\text { for Standard }\end{array}$ & 1.8 & 1.8 & 1.2 & 1.4 & 1.8 & 1.3 & 2.4 & 2.5 & 4 & 4.0 & 3.5 & 3.0 \\
\hline & \multirow{3}{*}{$2156 \mathrm{~Pa}$} & Standard & 0.0266 & 0.0266 & 0.0182 & 0.0503 & 0.0315 & 0.0353 & 0.0437 & 0.0084 & 0.1745 & 0.0851 & 0.1180 & 0.1120 \\
\hline & & High humidity & 0.0304 & 0.0304 & 0.0375 & 0.0692 & 0.0443 & 0.0361 & 0.0503 & 0.0253 & 0.488 & 0.3960 & 0.4091 & 0.2556 \\
\hline & & $\begin{array}{l}\text { Ratio of High humidity } \\
\text { for Standard }\end{array}$ & 1.7 & 1.7 & 2.7 & 1.4 & 1.4 & 1 & 1.2 & 3 & 2.8 & 4.7 & 3.5 & 2.3 \\
\hline \multirow{6}{*}{$\begin{array}{c}\mathrm{v} \\
\left(\mathrm{s}^{-1}\right)\end{array}$} & \multirow{3}{*}{$1176 \mathrm{~Pa}$} & Standard & 0.1066 & 0.1066 & 0.095 & 0.103 & 0.0462 & 0.0459 & 1.3582 & 0.143 & 0.0129 & 0.0255 & 0.0120 & 0.0496 \\
\hline & & High humidity & 0.0078 & 0.0078 & 0.0105 & 0.008 & 0.0193 & 0.0047 & 0.006 & 0.0278 & 0.0049 & 0.0048 & 0.0064 & 0.0072 \\
\hline & & $\begin{array}{l}\text { Ratio of High humidity } \\
\text { for Standard }\end{array}$ & 0.1 & 0.1 & 0.1 & 0.1 & 0.4 & 0.1 & 0.004 & 0.2 & 0.4 & 0.2 & 0.5 & 0.1 \\
\hline & \multirow{3}{*}{$2156 \mathrm{~Pa}$} & Standard & 0.1019 & 0.1019 & 0.1287 & 0.1188 & 0.0482 & 0.0242 & 0.8689 & 0.1274 & 0.0065 & 0.0117 & 0.0060 & 0.0194 \\
\hline & & High humidity & 0.0163 & 0.0163 & 0.007 & 0.009 & 0.0077 & 0.0093 & 0.0077 & 0.0072 & 0.0055 & 0.0122 & 0.0103 & 0.0088 \\
\hline & & $\begin{array}{l}\text { Ratio of High humidity } \\
\text { for Standard }\end{array}$ & 0.1 & 0.1 & 0.1 & 0.1 & 0.2 & 0.4 & 0.01 & 0.1 & 0.8 & 1.0 & 1.7 & 0.5 \\
\hline
\end{tabular}




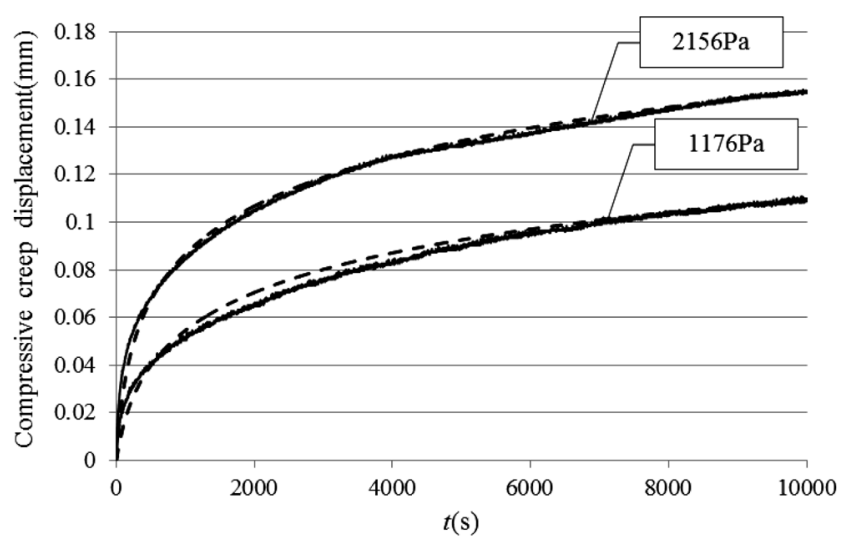

Fig. 11 The comparison between experimental curve and calculated curve using equation (2) for WPE-1.

Solid line: experimental

Broken line : calculated

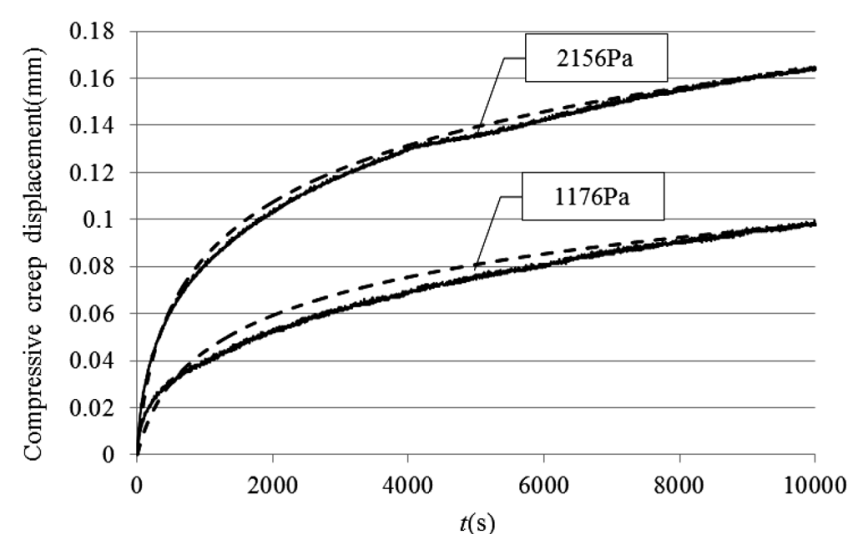

Fig. 12 The comparison between experimental curve and calculated curve using equation (2) for RPE-3.

Solid line : experimental

Broken line: calculated

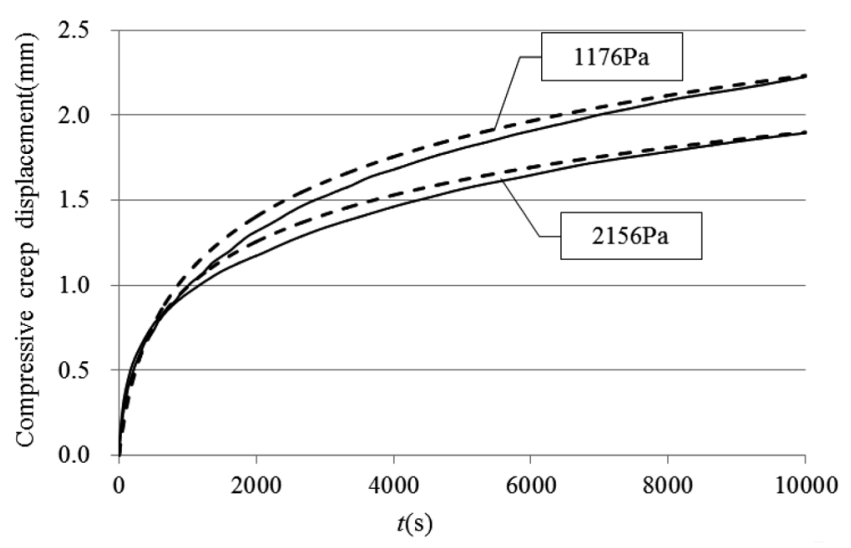

Fig. 13 The comparison between experimental curve and calculated curve using equation (2) for CU-3.

Solid line : experimental

Broken line : calculated

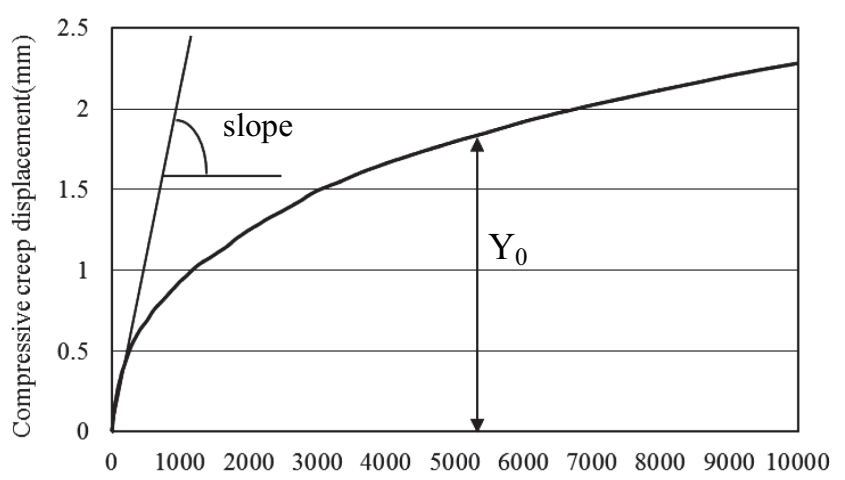

$t(\mathrm{~s})$

Fig. 14 Procedure to obtain parameters $Y_{0}$ and $V_{\text {ini }}$.

ここで $\mathrm{Y}_{0}$ とににいてその物理的意味を検討する. Fig. 14 にその考え方を示す． $\mathrm{Y}_{0}$ 值は任意時間における圧縮ク リープ変形の大きさ $(\mathrm{mm})$ を表わすパラメータである. 前述 したように再繊維集合体の圧縮クリープ変形量は合成繊維維 集合体よりも明らかに大きい。このことは, Table 3 の各圧 縮応力条件における $\mathrm{Y}_{0}$ 值の大小に現れている. 低圧縮応力 条件下では合成繊維の $Y_{0}$ 值が $0.0144 \sim 0.0703$ の範囲にある のに対し, $C U-1,2,3$ の $\mathrm{Y}_{0}$ 值は $0.5290 \sim 0.5851$ の範囲, LY は 0.4237 である。高圧縮応力条件下では合成繊維の $\mathrm{Y}_{0}$ 值が 0.0219 0.0692の範囲にあるのに対し, $\mathrm{CU}-1,2,3$ の $\mathrm{Y}_{0}$ 值は 0.3960 0.4880の範囲，LYは 0.2556 である.いずれの圧縮 応力条件においても再生繊維集合体の $\mathrm{Y}_{0}$ 值は合成繊維集合 体に比べておよそ 1 桁大きい. また CU-1, 2, 3 について標準 試料と高湿試料を比較すると, 高湿試料は標準試料の $3 \sim 5$ 倍も大きい. 吸湿性の高い $\mathrm{CU}-1,2,3$ の圧縮クリープ変形に おいては, 前報 [5] で報告した圧縮応力緩和現象と同様に, 水分の作用は繊維内に吸湿された水分子（キュプラの場合, 平衡水分率は標準状態での $11.0 \%$ から高湿条件での $19.6 \%$ に 変化している）による分子鎖の流動性の増大, 結果としての 曲げ剛性の低下として現れ, 圧縮クリープ変形が著しく大き くなったものと考えられる.

次に, $\mathrm{v}$ 值について検討する。式(2) を時間 $t$ について微 分し, $\mathrm{t}=0$ と置くと次のようになる.

$$
\left.\frac{d}{d t}\left\{Y_{0} \ln (v t+1)\right\}\right|_{t=0}=\left.\frac{Y_{0} \cdot v}{v t+1}\right|_{t=0}=Y_{0} \cdot v
$$

したがって, $\mathrm{Y}_{0} \cdot \mathrm{v}$ は圧縮クリープ曲線の $\mathrm{t}=0$ における接 線すなわち初期変形速度となる。これを $\mathrm{V}_{\mathrm{ini}}$ とすると,

$$
\mathrm{V}_{\text {ini }}=\mathrm{Y}_{0} \cdot \mathrm{v}
$$

以上のように, パラメータ $\mathrm{v} は, \mathrm{Y}_{0} \cdot \mathrm{v}$ という積の形で初 期変形速度という物理的意味を持つことになる。各試料の $\mathrm{V}_{\text {ini }}$ を Table 4 に示す. Fig. 15 は低圧縮応力時, Fig. 16 は高 圧縮応力時の標準試料と高湿試料の $\mathrm{V}_{\mathrm{ini}}$ を比較している。合 成繊維集合体については高湿試料の方が標準試料に比べてか なり小さい，それに対して, CU-1, 2, 3 は高湿試料の方が標 準試料に比べて大きい，これは水分の効果が合成繊維集合体 
Table 4 The calculated values of initial tangent speed: $V_{\text {ini. }}$.

\begin{tabular}{|c|c|c|c|c|c|c|c|c|c|c|c|c|c|c|}
\hline \multicolumn{3}{|c|}{ Sample code } & WPE-1 & WPE-1 & WPE-3 & RPE-1 & RPE-2 & RPE-3 & RPE-4 & PTT & CU-1 & $\mathrm{CU}-2$ & $\mathrm{CU}-3$ & LY \\
\hline \multirow{4}{*}{$\mathrm{V}_{\text {ini }}$} & \multirow{2}{*}{$1176 \mathrm{~Pa}$} & Standard & $1.49 \mathrm{E}-03$ & $2.95 \mathrm{E}-04$ & $1.68 \mathrm{E}-03$ & $5.16 \mathrm{E}-03$ & $1.56 \mathrm{E}-03$ & $9.24 \mathrm{E}-04$ & $3.19 \mathrm{E}-02$ & $1.40 \mathrm{E}-03$ & $1.86 \mathrm{E}-03$ & $3.35 \mathrm{E}-03$ & $1.82 \mathrm{E}-03$ & $7.07 \mathrm{E}-03$ \\
\hline & & High humidity & $1.96 \mathrm{E}-04$ & $2.37 \mathrm{E}-04$ & $2.28 \mathrm{E}-04$ & $5.61 \mathrm{E}-04$ & $1.17 \mathrm{E}-03$ & $1.20 \mathrm{E}-04$ & $3.35 \mathrm{E}-04$ & $6.66 \mathrm{E}-04$ & $2.89 \mathrm{E}-03$ & $2.54 \mathrm{E}-03$ & $3.43 \mathrm{E}-03$ & $3.07 \mathrm{E}-03$ \\
\hline & \multirow{2}{*}{$2156 \mathrm{~Pa}$} & Standard & $2.71 \mathrm{E}-03$ & $8.07 \mathrm{E}-04$ & $2.34 \mathrm{E}-03$ & $5.98 \mathrm{E}-03$ & $1.52 \mathrm{E}-03$ & $8.53 \mathrm{E}-04$ & $3.80 \mathrm{E}-02$ & $1.07 \mathrm{E}-03$ & $1.14 \mathrm{E}-03$ & $9.95 \mathrm{E}-04$ & $7.05 \mathrm{E}-04$ & $2.17 \mathrm{E}-03$ \\
\hline & & High humidity & $4.96 \mathrm{E}-04$ & $2.77 \mathrm{E}-04$ & $2.63 \mathrm{E}-04$ & $6.23 \mathrm{E}-04$ & $3.40 \mathrm{E}-04$ & $3.37 \mathrm{E}-04$ & $3.87 \mathrm{E}-04$ & $1.82 \mathrm{E}-04$ & $2.67 \mathrm{E}-03$ & $4.83 \mathrm{E}-03$ & $4.21 \mathrm{E}-03$ & $2.25 \mathrm{E}-03$ \\
\hline
\end{tabular}

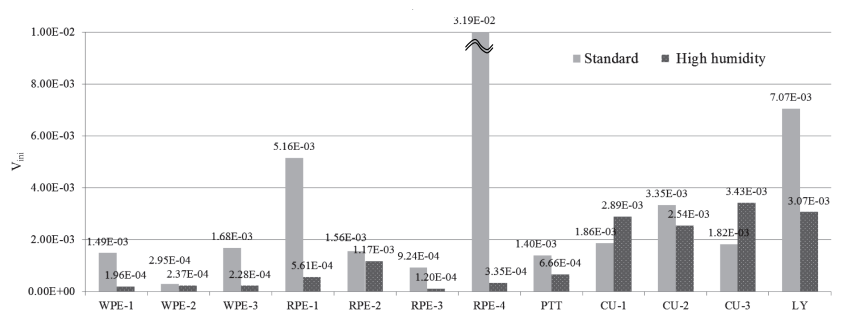

Fig. 15 The initial tangent speed: $V_{\text {ini }}$ on standard condition and high humidity condition when the compression stress is $1176 \mathrm{~Pa}$.

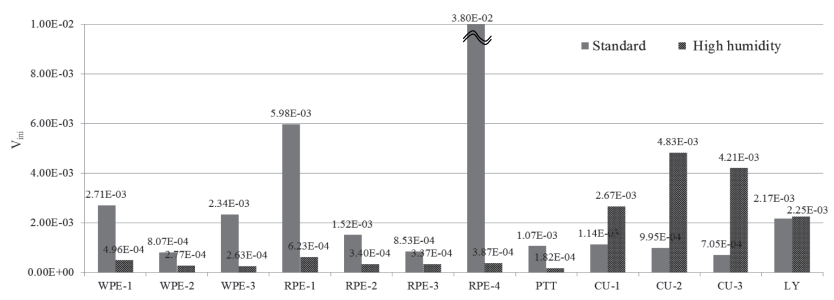

Fig. 16 The initial tangent speed: $V_{\text {ini }}$ on standard condition and high humidity condition when the compression stress is $2156 \mathrm{~Pa}$.

とキュプラ繊維集合体で，逆の作用としてはたらいたものと 考えられる. 合成繊維集合体では水分の効果は繊維同士の滑 りを小さくする方向に作用し，キュプラ繊維集合体において は，水分の作用のひとつとして繊維内に吸湿された水分子に よる分子鎖の流動性の増大に作用しているものと推測され る。（ただし RPE-4 は標準条件で顕著に大きい。これは中空 円筒状繊維であるため, 曲げ座屈現象が生じたものと推測さ れる.）

以上の結果より，高湿環境下における合成繊維集合体およ び再生繊維集合体の圧縮クリープ変形挙動は非線形 3 要素モ デルで表されると結論できる.

\section{4. 結 言}

本研究では，寝装用中わた部材を構成する繊維として現在 流通している試料の中から, 異型断面ポリエステル, 丸断面 ポリエステル，中空断面ポリエステルおよびポリトリメチレ ンテレフタレートなどの合成繊維や，キュプラおよびリヨセ ルなどの再生繊維について 12 種の短繊維集合体を採り上げ, 実使用時を想定した高湿環境のもとでこれらの圧縮クリープ
特性について検討し，以下の結果を得た。

（1）いずれの圧縮応力条件においても，合成繊維集合体 に比べて吸湿性の高い再生繊維集合体の圧縮クリープ変形率 は顕著に大きい

(2) 同一繊度及び同一繊維長の試料（WPE-1, RPE-1, CU-1）について圧縮クリープ変形率を比較すると, WPE-1 が最も小さく, 次いで RPE-1, CU-1 の順で大きい. RPE-3 と RPE-4 については, RPE-3 に比べて RPE-4 の方が大き い.

(3) 繊度が 1.3〜 6.6 dtex, 繊維長が 38〜 $51 \mathrm{~mm}$ の範囲に ある同素材間の短繊維集合体については, 繊度と繊維長の違 いにより圧縮クリープ変形率に有意な差は見られない.

(4) 高圧縮応力時の方が低圧縮応力時よりクリープ変形 率が大きくなる傾向がある.

（５）高湿環境下における合成繊維集合体および再生繊維 集合体の圧縮クリープ変形挙動は非線形 3 要素モデルで表さ れ，標準試料と同様に，次のようなクリープ表示式で表され る.

$$
\varepsilon_{t}=\mathrm{Y}_{0} \ln (v t+1)
$$

ここで, $\mathrm{Y}_{0}(\mathrm{~mm})$ および $\mathrm{v}\left(\mathrm{s}^{-1}\right)$ は試料の物性および測定条 件等によって決まる定数である.

（6） $\mathrm{Y}_{0}$ は任意時間における圧縮クリープ変形の大きさを 表わすパラメータである。高湿条件において，再生繊維集合 体は合成繊維集合体に比べて， $\mathrm{Y}_{0}$ がおよそ 1 林大きい，パ ラメータ $\mathrm{v}$ は $\mathrm{V}_{\mathrm{ini}}=\mathrm{Y}_{0} \cdot \mathrm{v}$ の形で物理的意味を持ち, $\mathrm{V}_{\text {ini }}$ は圧 縮クリープ変形の初期接線速度を表わす。合成繊維集合体で は高湿試料の方が標準試料に比べて $\mathrm{V}_{\mathrm{ini}}$ はかなり小さく, キュプラ繊維集合体では高湿試料の方が標準試料に比べて大 きい.

以上の結果をもたらす理由として, 高湿条件における水分 の作用が合成繊維集合体と再生繊維集合体において異なって いることについて考察を加えた，合成繊維集合体では水分の 効果は繊維同士の滑りを小さくする方向に作用し, キュプラ 繊維集合体においては水分の作用のひとつとして繊維内に吸 湿された水分子による分子鎖の流動性の増大に作用している ものと推測される。

本研究では, 寝床内気候が高湿環境であることを想定し, 実使用に近い高湿条件下における短繊維の集合構造体として の圧縮クリープ機構について，粘弾性モデルにもとづいて検 討を行なった。得られたいくつかの知見は，短繊維集合体の 基本的な力学特性としてだけでなく，敷きふとんなどの寝装 
用繊維製品の設計および寝心地に関わる実使用性能を評価す る基礎資料として意義あるものと考えられる.

\section{謝 辞}

本研究を遂行するにあたり，貴重な試料をご提供して頂き ました旭化成せんい株式会社および旧ソロテックス株式会 社，加湿調整装置の作製と圧縮クリープ試験機改良にご協力 頂きましたカトーテック株式会社の関係各位に深謝します。

\section{References}

[1] Nakajima C, Yoneda M Itoh Y (2010) J Text Eng, 56, 29-38

[2] Nakajima C, Yoneda M, Itoh Y (2010) J Text Eng, 56, $39-46$

[3] Nakajima C, Yoneda M (2010) J Text Eng, 56, 139-146

[4] Nakajima C, Yoneda M, Nishioka S, Miyazaki A (2010) J
Text Eng, 56, 195-202

[5] Yoneda M, Nakajima C, Yanagihara A (2012) J Text Eng 58, 77-88

[6] Yokura H, Sukigara S, Niwa M (1995) Jpn Res Assn Text End-Uses, 36, 594-601

[7] Yokura H, Sukigara S, Niwa M (1996) Jpn Res Assn Text End-Uses, 37, 535-543

[8] Nogai T, Narumi Y (1972) J Text Mach Soc Japan (predecessor journal of J Text Eng), 25, T180-T188

[9] Nogai T, Narumi Y , Tanaka K (1974) J Text Mach Soc Japan (predecessor journal of J Text Eng), 27, T177-T182

[10] Nogai T, Narumi Y , Tanaka K (1975) J Text Mach Soc Japan (predecessor journal of J Text Eng), 27, T177-T182

[11] Sukigara S, Yokura H, Niwa M (1994) Proc. 23th Text Res Symp, 108-114

[12] Yasuda T (1962) Jpn Res Assn Text End-Uses, 3, 310-315 